Frequency of Chlamydia trachomatis, Mycoplasma genitalium, and Ureaplasma urealyticum Isolated From Vaginal Samples of Women in

\title{
Kerman, Iran
}

\author{
Zahra Zahirnia ${ }^{1}$, Shahla Mansouri ${ }^{1,{ }^{*}}$, Fereshteh Saffari ${ }^{1}$ and Ghazal Mansouri ${ }^{2}$ \\ ${ }^{1}$ Department of Microbiology and Virology, School of Medicine, Kerman University of Medical Sciences, Kerman, Iran \\ ${ }^{2}$ Department of Obstetrics and Gynecology, Kerman University of Medical Sciences, Kerman, Iran \\ "Corresponding author: Department of Microbiology and Virology, School of Medicine, Kerman University of Medical Sciences, Kerman, Iran. Tel/Fax: +98-3433221665, Email: \\ smansouri@kmu.ac.ir
}

Received 2017 December 19; Revised 2018 June 30; Accepted 2018 July 08.

\begin{abstract}
Background: Chlamydia trachomatis, Mycoplasma genitalium, and Ureaplasma urealyticum are genital infectious agents that can be sexually transmitted. They are involved in many infections both in women and men and can also be the cause of abortion in women. Objectives: This study aimed to determine the prevalence of the aforementioned bacteria in pregnant women and those with abortion in Kerman, southeast of Iran. Totally, 200 vaginal specimens were taken from pregnant women $(n=76)$ and those with abortion $(\mathrm{n}=124)$ and were investigated for chlamydial and mycoplasmal infections using polymerase chain reaction (PCR) assay.

Methods: From December 2015 to December 2016, 200 women were enrolled in this study. Demographic and behavioral information were gathered for statistical analysis. The prevalence of bacteria was determined in the vaginal samples by PCR.

Results: All the studied bacteria were more frequently isolated from women with abortion, that is, $34.6 \%$ versus $15.7 \%$ for $U$. urealyticum, $20.9 \%$ versus $17.1 \%$ for M. genitalium, and $15.3 \%$ versus $10.5 \%$ for C. trachomatis. However, only for $U$. urealyticum the difference was significant $(\mathrm{P}=0.0006)$. Again, occurrence of co-infection was mostly detected in women with abortion, and co-infection of $U$. urealyticum and $M$. genitalium was significantly higher $(\mathrm{P} \leq 0.03)$. Also, follow-up studies indicated the importance of $U$. urealyticum in adverse outcomes of pregnancy in this region. Thus, special attention should be paid to this infection during pregnancy.

Conclusions: The present study showed a significantly high prevalence of U. urealyticum in women with abortion separately and also in combination with M. genitalium. Diagnostic tests are recommended to detect these bacteria in high-risk women.
\end{abstract}

Keywords: Abortion, Chlamydia trachomatis, Mycoplasma genitalium, Ureaplasma urealyticum, Pregnant Women, Vaginal Swab

\section{Background}

Sexually transmitted infections (STIs) are of global public health problems (1). Among different known STIs, chlamydial and mycoplasmal infections are of great concern because of their association with postoperative difficulties and termination of pregnancy (TOP) (1). Although the causative agents are entirely different, they have similar clinical manifestations (2). It has been reported that C. trachomatis, M. genitalium, and U. urealyticum are all involved in genitourinary tract infections, abortions, premature rupture of membranes (PROM), and prenatal mortality or stillbirth (3).

C. trachomatis is of the most important common pathogens involved in sexually transmitted diseases (STDs) worldwide, accounting for 600,000 reported cases annually in USA $(3,4)$. It is a major cause of pelvic inflammatory disease (PID), mucopurulent cervicitis, tubal infertility (5), ectopic pregnancies, preterm birth, and cervical or ovarian cancers (2-4). According to the Center for Disease Control, approximately $4.7 \%$ - $14 \%$ of C. trachomatis infections occur during pregnancy (6).

In Iran, the isolation frequency of C. trachomatis was reported to be up to $23 \%$ in pregnant women $(7,8)$ and about $11 \%-13 \%$ in women with abortion (7-9). Among other causative agents of STDs, there are Mycoplasma spp. including M. genitalium and U. urealyticum. These organisms are free-living with small genomes and low metabolic activities, and their association with nongonococcal urethritis (NGU) has been reported (10). In this respect, the prevalence of $M$. genitalium among female partners of men infected with NGU has been reported to be $32 \%$ (10). M. genitalium has also been detected in $56 \%$ of male sexual partners of infected women (11). The role of $M$. genitalium in more severe infections such as cervicitis and PID 
has been demonstrated (12), and a significant association has been reported between $M$. genitalium infection and preterm birth, younger maternal age, and low body mass index (13). U. urealyticum is among the most common organisms causing adverse infections of the amniotic fluid and placenta (9). It is known as a normal flora in the lower genital tract, but its association with STDs is still controversial (9). To the best of our knowledge, this is the first report about the frequencies of $C$. trachomatis, $U$. urealyticum, and $M$. genitalium infections in pregnant or women with abortion in southeast of Iran.

\section{Objectives}

The aim of this study was to determine the prevalence of infections with mentioned organisms in vaginal samples of women with abortion in comparison with pregnant women. Besides, the association between the presence of these infections and socio-demographic parameters was determined.

\section{Methods}

\subsection{Study Design}

In this cross-sectional study conducted from December 2015 to December 2016, 200 vaginal swabs were taken from 124 women who had experienced abortions and 76 pregnant women referring to /or hospitalized at the gynecology department of a university-affiliated hospital in Kerman, Iran. The sample size was determined by an expert statistician. All the volunteers enrolled in this study were asked for some socio-demographic data (e.g., age, education, and place of residence), history of abortion, premature delivery, genital and urinary tract infections through filling out a questionnaire and face to face interviews (Table 1).

\subsection{Samples and Microbiological Procedures}

Specimen collection was performed by inserting 2 - 3 $\mathrm{cm}$ of a Dacron swab (Delta Lab, Spain) into the vagina and rotating it in order to obtain a great number of cells. All the specimens were placed into Trypticase soy broth (Conda, Spain) containing $0.6 \%$ yeast extract (BBL, USA) and were transferred on ice to laboratory for further processing (14). DNA extraction was performed using High Pure PCR Template Preparation Kit (Roche, Germany) according to manufacturer's instruction. Eluted DNA was stored at $-20^{\circ} \mathrm{C}$ for further analysis.

\subsection{PCR Assay}

DNA extraction and amplification for all polymerase chain reaction (PCR) and nested PCR assays were performed using Pars Tous kit (Arya Tous CO. Iran), which amplifies outer membrane protein 1 (omp 1) of C. trachomatis, P protein (mgpa) of M. genitalium, and urease of U. urealyticum $(9,15,16)$. For $C$. trachomatis, nested PCR was performed according to the kit's instructions (Table 2). The amplified products were subjected to electrophoresis using $1.5 \%$ agarose gel.

\subsection{Statistical Analysis}

Statistical analysis was performed using SPSS, version 20. T-test was performed to analyze the relationship between the presence of infections and demographic variables. P-value less than 0.05 was considered statistically significant.

\subsection{Ethical Considerations}

This study was performed under approval of institutional review board of Kerman University of Medical Sciences (IR.KMU.REC.1395.339). Written informed consent form was obtained from all the participant in this study.

\section{Results}

Overall, 200 women were recruited, of whom $92.7 \%$ were Iranian women and 7.3\% were Afghans. The mean age of the pregnant women and those with abortion was $32 \pm$ 2.8 and $31 \pm 3.1$ years, respectively. Also, history of genitourinary infection was reported in $40.42 \%$ of the subjects.

C. trachomatis was found in $15.32 \%$ (19/124) of aborted and $10.52 \%(8 / 76)$ of pregnant women. In the pregnant group, association between infection and gestational age was significant, such that $9.3 \%$ of the specimens from pregnant women which were positive for $C$. trachomatis, were recovered from women at the third trimester (vs. 1.32\% for women with abortion; $\mathrm{P} \leq 0.05$ ). The frequency of the studied bacteria and co-infection rates are shown in Table 3.

No co-infection with the three studied microorganisms was found, while co-infection with two microorganisms was more frequently found in abortion group (23.3\%) in comparison with pregnant one (7.89\%). However, only high frequency of co-infection with M. genitalium and $U$. urealyticum was statistically significant $(\mathrm{P}=0.03$; Table 3$)$.

Co-infection with C. trachomatis and M. genitalium was only detected in Afghan women older than 25 years old, while co-infection with $C$. trachomatis and $U$. urealyticum was more frequently observed in women younger than 25 years old who had history of vaginal infection and PROM; however, this difference was not significant. Co-infection 


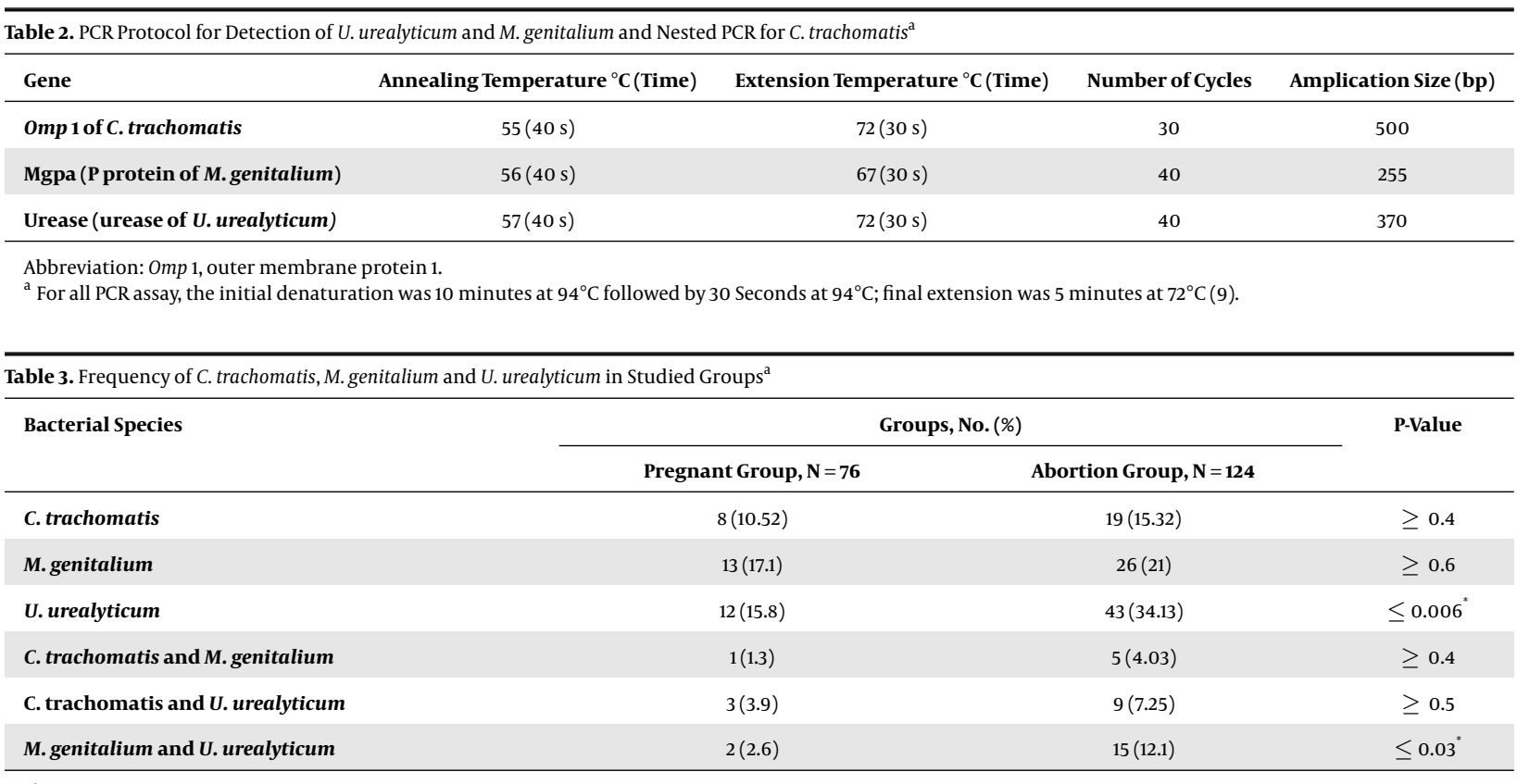

$\mathrm{a}^{*}$ Statistically significant.

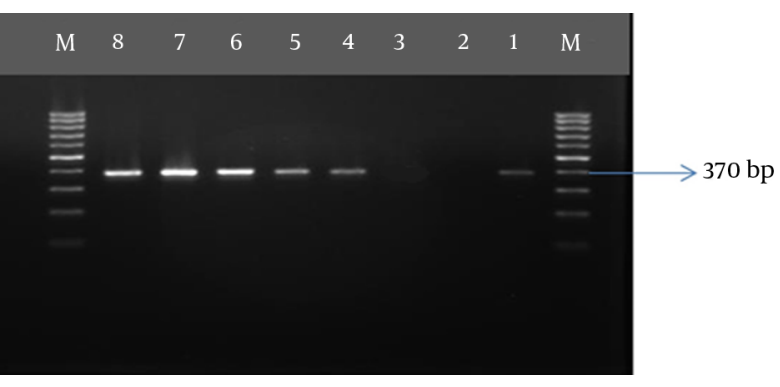

Figure 1. PCR products of Urease encoding gene in U. urealyticum (370 bp), Lane 1, positive control; lanes 4 - 8 positive samples; lane 3, negative control; Lane M, 100 bp size marker.

with C. trachomatis and U. urealyticum was mostly detected in women who had previously experienced abortion. The demographic data of $C$. trachomatis, M. genitalium, and $U$. urealyticum-positive patients are summarized in Tables 4 and 5 in both pregnant and abortion groups. Gel agarose electrophoresis for detection of genes representative for $C$. trachomatis, M. genitalium, and U. urealyticum are displayed in Figures 1-3.

\section{Discussion}

Abortion remains a major public health concern worldwide and is usually a consequence of serious genital tract infections. Among important genital bacteria causing infections, there are U. urealyticum, M. genitalium, and

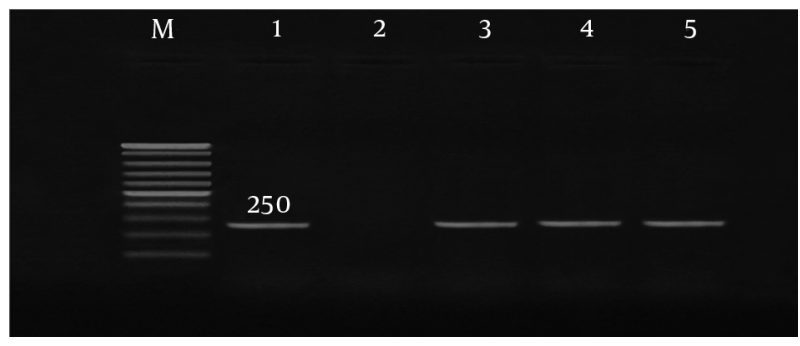

Figure 2. PCR products of omp encoding gene in C. trachomatis (250 bp), Lane 1, positive control; lanes 3 - 5 positive samples; lane 2, negative control; Lane M, 100 bp size marker.

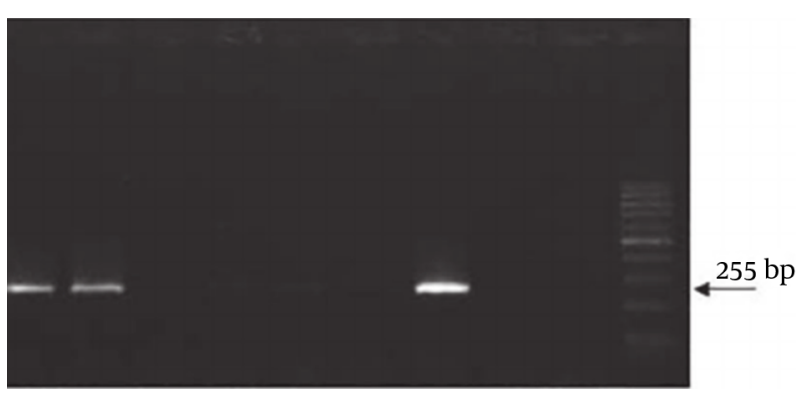

Figure 3. PCR products of mgpa gene in M. genitalium ( $255 \mathrm{bp}$ ), Lane 3, positive control; lanes 8 - 9 positive samples; lane 2, negative control; Lane M, 100 bp size marker.

C. trachomatis $(13,17,18)$. Depending on the type of sample and different methods of isolation, different frequencies 
for these bacteria are reported. For example, the frequencies of C. trachomatis among women with TOP in Swiss, Sweden, New Zealand, and Poland were 16.37\%, 5.4\%, 15.7\%, and $32 \%$, respectively $(16,19-21)$. In Iran (Tehran) and Iraq, the rates of $13.25 \%$ and $6.4 \%$ have been reported, respectively $(9,22)$. Our result is similar to the reported case from Swiss and higher than those reported from Iran (19).

In pregnant women, the prevalence of $C$. trachomatis has been reported from $1 \%$ in Saudi Arabia to $13.6 \%$ in Iraq (23-26). In Iran, the isolation of C. trachomatis from various regions was reported to range from $2.9 \%$ to $13.7 \%(8,27-$ 29). The frequency of $C$. trachomatis in this study was $10.52 \%$, which is in line with the reported range of isolation from our country. The difference in the isolation frequency of these bacteria can be attributed to the type of samples, the methods of isolation, and understudied patients.

M. genitalium infection among women with TOP in Denmark, Sweden, and Iran in 2013 and 2014 ranged from $0.91 \%$ to $16.5 \%$. Our results (21\%) were in accordance with the reported case in Iran in $2014(16,23,30,31)$. The infection rates of $M$. genitalium among pregnant women in the UK, New Zealand, USA, and Sweden were 0.7\%, 8.7\%, $6.7 \%$, and $2.8 \%$, respectively $(16,20,32,33)$. Besides, the prevalence of $M$. genitalium among pregnant women in various regions of Iran is varied, such that it was $1.02 \%$ in Sabzevar, $22.7 \%$ in Tonekabon, and $2.75 \%$ in Sanandaj $(8,23,31)$. Herein, we observed that $22.41 \%$ and $17.1 \%$ of women with abortion and pregnant women were infected with $M$. genitalium, respectively, that is similar to Tonekabon report.

Difference in $U$. urealyticum isolation in various specimens has been reported, such that it was 10\% among women with TOP in Iran and $74.1 \%$ in China $(15,34)$, and in pregnant women in Iran, it ranged from $7.3 \%$ to $15.2 \%$ $(15,35)$. In this study, U. urealyticum was isolated more frequently from the abortion group and we found a higher frequency of this bacterium than other studies in our country. The important role of $U$. urealyticum in various vaginal infections, resulting in pyelonephritis, PID, chorioamnionitis, and postpartum and postabortal fever, has been implicated in many studies (15). In addition, the co-infection of U. urealyticum and Mycoplasma hominis has been reported to increase the risk for adverse pregnancy outcomes in high-risk patients such as those with premature labor or PROM (36).

Various studies have focused on the relationship between risk factors and STIs in women (3). In some studies, association between maternal age (young women) and infection with $C$. trachomatis and $M$. genitalium has been reported $(4,7,37)$. However, in other studies, in accordance with our research, no association was found between maternal age and the presence of C. trachomatis and M. genitalium (32). Other demographic factors that have been associ- ated with these bacteria were contraceptive method, history of PROM, gestational age, and history of miscarriage $(7,15,37,38)$. In our study, there was a significant correlation between $C$. trachomatis infection and mother's educational level in women who experienced abortion. Also, $C$. trachomatis infection was found to be significantly more prevalent in pregnant women in the third trimester of pregnancy compared to other times.

M. genitalium was found to be more frequent in rural and Afghan women in the pregnant group compared to the abortion group. Since neither the studied risk factors nor the study groups are similar in all studies, comparing the results is difficult. History of PROM was correlated with C. trachomatis infection according to Ahmadi et al. (7), while we found that history of PROM was more prevalent in patients co-infected with C. trachomatis and M. genitalium. There are some differences in cultural issues such as having different partners, which make comparison limited. Another limitation is the kind of specimen or sampling methods as well as various identification methods used in different studies. We used vaginal swabs for detection of the bacteria since this method is reported to give a high load of bacteria $(9,39)$.

In conclusion, we found that $U$. urealyticum is an important cause of infection in pregnant women in this region and its role in abortion and abnormalities needs special attention. Our follow-up studies indicated the important role of $U$. urealyticum in adverse outcomes of pregnancy. However, a higher number of cases should be examined and diagnostic screening tests should be performed in order to reduce the risk of premature stillbirth or abortions due to these infections. Gynecologists should adopt proper plans for the diagnosis and treatment of these infections in order to diminish the resulting complications in women.

\section{Acknowledgments}

We are grateful to Ms. Moghadasi for assistance in sampling. Funds for the study were provided (grant number: 1395.339) from research council, Faculty of Medicine, Kerman University of Medical Sciences, Kerman, Iran.

\section{References}

1. Rumyantseva T, Golparian D, Nilsson CS, Johansson E, Falk M, Fredlund $\mathrm{H}$, et al. Evaluation of the new AmpliSens multiplex real-time PCR assay for simultaneous detection of Neisseria gonorrhoeae, Chlamydia trachomatis, Mycoplasma genitalium, and Trichomonas vaginalis. APMIS. 2015;123(10):879-86. doi:10.1111/apm.12430. [PubMed: 26299582] 
2. Ljubin-Sternak S, Mestrovic T. Chlamydia trachomatis and genital mycoplasmas: Pathogens with an impact on human reproductive health. J Pathog. 2014;2014:183167. doi: 10.1155/2014/183167. [PubMed: 25614838]. [PubMed Central: PMC4295611].

3. Pinto VM, Szwarcwald CL, Baroni C, Stringari LL, Inocencio LA, Miranda AE. Chlamydia trachomatis prevalence and risk behaviors in parturient women aged 15 to 24 in Brazil. Sex Transm Dis. 2011;38(10):957-61. doi: 10.1097/OLQ.0b013e31822037fc. [PubMed: 21934572].

4. Baud D, Goy G, Jaton K, Osterheld MC, Blumer S, Borel N, et al. Role of Chlamydia trachomatis in miscarriage. Emerg Infect Dis. 2011;17(9):1630-5. doi: 10.3201/eid1709.100865. [PubMed: 21888787]. [PubMed Central: PMC3322049].

5. Omo-Aghoja LO, Okonofua FE, Onemu SO, Larsen U, Bergstrom S. Association of Chlamydia trachomatis serology with tubal infertility in Nigerian women. J Obstet Gynaecol Res. 2007;33(5):688-95. doi: 10.1111/j.1447-0756.2007.00633.x. [PubMed:17845331].

6. Center for Disease Control and Prevention (CDC). 2018. Available from: www.CDC.gov.

7. Ahmadi A, Khodabandehloo M, Ramazanzadeh R, Farhadifar F, Roshani D, Ghaderi E, et al. The relationship between chlamydia trachomatis genital infection and spontaneous abortion. $J$ Reprod Infertil. 2016;17(2):110-6. [PubMed: 27141466]. [PubMed Central: PMC4842232].

8. Haghighi Hasanabad M, Mohammadzadeh M, Bahador A, Fazel N, Rakhshani H, Majnooni A. Prevalence of Chlamydia trachomatis and Mycoplasma genitalium in pregnant women of Sabzevar-Iran. Iran J Microbiol. 2011;3(3):123-8. [PubMed: 22347594]. [PubMed Central: PMC3279818].

9. Eslami G, Goudarzi H, Taheripanah R, Taheri S, Fallah F, Moazzami B, et al. Chlamydia trachomatis detection by nested-pcr method on females referred to medical centers of Tehran, Iran. Arch Clin Infect Dis. 2012;7(4):124-7. doi: 10.5812/archcid.15087.

10. Keane FE, Thomas BJ, Gilroy CB, Renton A, Taylor-Robinson D. The association of Mycoplasma hominis, Ureaplasma urealyticum and Mycoplasma genitalium with bacterial vaginosis: Observations on heterosexual women and their male partners. Int J STD AIDS. 2000;11(6):356-60. doi: 10.1258/0956462001916056. [PubMed: 10872907].

11. Zheng BJ, Yin YP, Han Y, Shi MQ, Jiang N, Xiang Z, et al. The prevalence of urethral and rectal Mycoplasma genitalium among men who have sex with men in China, a cross-sectional study. BMC Public Health. 2014;14:195. doi: 10.1186/1471-2458-14-195. [PubMed: 24559387]. [PubMed Central: PMC3938087].

12. Bjartling C, Osser S, Persson K. Mycoplasma genitalium in cervicitis and pelvic inflammatory disease among women at a gynecologic outpatient service. Am J Obstet Gynecol. 2012;206(6):476 e1-8. doi: 10.1016/j.ajog.2012.02.036. [PubMed: 22483084].

13. Hitti J, Garcia P, Totten P, Paul K, Astete S, Holmes KK. Correlates of cervical Mycoplasma genitalium and risk of preterm birth among Peruvian women. Sex Transm Dis. 2010;37(2):81-5. doi: 10.1097/OLQ.ob013e3181bf5441. [PubMed: 20051932]. [PubMed Central: PMC4623580].

14. Domeika M, Litvinenko I, Smirnova T, Gaivaronskaya O, Savicheva A, Sokolovskiy E, et al. Laboratory diagnostics for non-viral sexually transmitted infections in St. Petersburg, Russia: Current situation and hallmarks for improvements. J Eur Acad Dermatol Venereol. 2008;22(9):1094-100. doi: 10.1111/j.1468-3083.2008.02739.x. [PubMed: 18410333].

15. Ahmadi A, Khodabandehloo M, Ramazanzadeh R, Farhadifar F, Nikkhoo B, Soofizade N, et al. Association between Ureaplasma urealyticum endocervical infection and spontaneous abortion. Iran J Microbiol. 2014;6(6):392-7. [PubMed: 25926956]. [PubMed Central: PMC4411424].

16. Bjartling C, Osser S, Persson K. The association between Mycoplasma genitalium and pelvic inflammatory disease after ter- mination of pregnancy. BJOG. 2010;117(3):361-4. doi: 10.1111/j.14710528.2009.02455.x. [PubMed: 20015303].

17. Haggerty CL, Totten PA, Astete SG, Ness RB. Mycoplasma genitalium among women with nongonococcal, nonchlamydial pelvic inflammatory disease. Infect Dis Obstet Gynecol. 2006;2006:30184. doi: 10.1155/IDOG/2006/30184. [PubMed: 17485798]. [PubMed Central: PMC1581464].

18. Manhart LE, Holmes KK, Hughes JP, Houston LS, Totten PA. Mycoplasma genitalium among young adults in the United States: An emerging sexually transmitted infection. Am J Public Health. 2007;97(6):1118-25. doi: 10.2105/AJPH.2005.074062. [PubMed: 17463380]. [PubMed Central: PMC1874220].

19. Wesbonk J, Chmiel C, Rosemann T, Seidenberg A, Senn O. Prevalence and determinants of sexually transmitted infections in women at risk undergoing abortion in a Swiss primary care setting. Praxis (Bern 1994). 2014;103(15):875-82. doi: 10.1024/1661-8157/a001724. [PubMed: 25051930].

20. Lawton BA, Rose SB, Bromhead C, Gaitanos LA, MacDonald EJ, Lund KA. High prevalence of Mycoplasma genitalium in women presenting for termination of pregnancy. Contraception. 2008;77(4):294-8. doi: 10.1016/j.contraception.2007.12.002. [PubMed: 18342654].

21. Magon T, Kluz S, Chrusciel A, Obrzut B, Skret A. The PCR assessed prevalence of Chlamydia trachomatis in aborted tissues. Med Wieku Rozwoj. 2005;9(1):43-8. [PubMed: 16082064].

22. Abdul-Karim ET, Abdul-Muhymen N, Al-Saadie M. Chlamydia trachomatis and rubella antibodies in women with full-term deliveries and women with abortion in Baghdad. East Mediterr Health J. 2009;15(6):1407-11. [PubMed: 20218131].

23. Mohseni R, Sadeghi F, Miri NM, Eghbali M, Dezhkame S, Ghane M. A study on the frequency of vaginal species of Mycoplasma genitalium, Gardnerella vaginalis and Neisseria gonorrhoeae among pregnant women by PCR technique. Int J Molecul Clin Microbiol. 2013.

24. Choi Y, Roh J. Cervical cytopathological findings in Korean women with Chlamydia trachomatis, Mycoplasma hominis, and Ureaplasma urealyticum infections. ScientificWorldJournal. 2014;2014:756713. doi: 10.1155/2014/756713. [PubMed: 24526918]. [PubMed Central: PMC3910385]

25. Alfarraj DA, Somily AM, Alssum RM, Abotalib ZM, El-Sayed AA, AlMandeel $\mathrm{HH}$. The prevalence of Chlamydia trachomatis infection among Saudi women attending the infertility clinic in Central Saudi Arabia. Saudi Med J. 2015;36(1):61-6. doi: 10.15537/smj.2015.1.9967. [PubMed: 25630006]. [PubMed Central: PMC4362201].

26. Shimano S, Nishikawa A, Sonoda T, Kudo R. Analysis of the prevalence of bacterial vaginosis and Chlamydia trachomatis infection in 6083 pregnant women at a hospital in Otaru, Japan.J Obstet Gynaecol Res. 2004;30(3):230-6. doi: 10.1111/j.1447-0756.2004.00181.x. [PubMed: 15210049].

27. Sohrabi A, Samarbafzadeh A, Makvandi M, Maraghi S, Razi T, Darban D. [A seroepidemiological study of Parvovirus B19, Toxoplasma gondii and Chlamydia trachomatis in pregnant women referring to Obs and Gyn ward of Ahwaz Imam Khomeini Hospital]. J Reproduction Infertility. 2007;8(2). Persian.

28. Jahromi AS, Farjam MR, Mogharrab F, Amiryan M, Makiani MJ, Madani A, et al. Chlamydia trachomatis in women with ful-term deliveries and women with abortion. Am J Infect Dis. 2010;6(3):66-9. doi: 10.3844/ajidsp.2010.66.69.

29. Khezerdoust S, Haghollahi F, Roostaie S, Badami N, Naghizadeh MM, Jafarabadi M. [Chlamydia trachomatis infection in pregnant women]. J Reproduct Infertility. 2009;10(2). Persian.

30. Baczynska A, Hvid M, Lamy P, Birkelund S, Christiansen G, Fedder J. Prevalence of Mycoplasma genitalium, Mycoplasma hominis and Chlamydia trachomatis among Danish patients requesting abortion. Syst Biol Reprod Med. 2008;54(3):127-34. doi: 10.1080/19396360802042838. [PubMed: 18570048].

31. Ramazanzadeh R, Khodabandehloo M, Farhadifar F, Rouhi S, Ah- 
madi A, Menbari S, et al. A Case-control Study on the Relationship between Mycoplasma genitalium Infection in Women with Normal Pregnancy and Spontaneous Abortion using Polymerase Chain Reaction. Osong Public Health Res Perspect. 2016;7(5):334-8. doi:10.1016/j.phrp.2016.07.001.[PubMed: 27812493]. [PubMed Central: PMC5079204].

32. Short VL, Jensen JS, Nelson DB, Murray PJ, Ness RB, Haggerty CL. Mycoplasma genitalium among young, urban pregnant women. Infect Dis Obstet Gynecol. 2010;2010:984760. doi: 10.1155/2010/984760. [PubMed: 20379360]. [PubMed Central: PMC2850137].

33. Oakeshott P, Hay P, Taylor-Robinson D, Hay S, Dohn B, Kerry S, et al. Prevalence of Mycoplasma genitalium in early pregnancy and relationship between its presence and pregnancy outcome. BJOG. 2004;111(12):1464-7. [PubMed: 15663138].

34. Ye LL, Zhang BY, Cao WL. [Relationship between the endocervical mycoplasma infection and spontaneous abortion due to early embryonic death]. Zhonghua Fu Chan Ke Za Zhi. 2004;39(2):83-5. [PubMed: 15059581].

35. Sobouti B, Fallah S, Mobayen M, Noorbakhsh S, Ghavami Y. Colonization of Mycoplasma hominis and Ureaplasma urealyticum in pregnant women and their transmission to offspring. Iran $J$ Microbiol. 2014;6(4):219-24. [PubMed: 25802703]. [PubMed Central:
PMC4367936].

36. Kwak DW, Hwang HS, Kwon JY, Park YW, Kim YH. Co-infection with vaginal Ureaplasma urealyticum and Mycoplasma hominis increases adverse pregnancy outcomes in patients with preterm labor or preterm premature rupture of membranes. J Matern Fetal Neonatal Med. 2014;27(4):333-7. doi: 10.3109/14767058.2013.818124. [PubMed: 23796000].

37. Hancock EB, Manhart LE, Nelson SJ, Kerani R, Wroblewski JK, Totten PA. Comprehensive assessment of sociodemographic and behavioral risk factors for Mycoplasma genitalium infection in women. Sex Transm Dis. 2010;37(12):777-83. doi: 10.1097/OLQ.0b013e3181e8087e. [PubMed: 20679963]. [PubMed Central: PMC4628821].

38. Manhart LE, Critchlow CW, Holmes KK, Dutro SM, Eschenbach DA Stevens CE, et al. Mucopurulent cervicitis and Mycoplasma genitalium. I Infect Dis. 2003;187(4):650-7. doi: 10.1086/367992. [PubMed: 12599082].

39. Schachter J, McCormack WM, Chernesky MA, Martin DH, Van Der Pol B, Rice PA, et al. Vaginal swabs are appropriate specimens for diagnosis of genital tract infection with Chlamydia trachomatis. J Clin Microbiol. 2003;41(8):3784-9. [PubMed: 12904390]. [PubMed Central: PMC179798]. 
Table 1. Demographic Data and Risk Factors of Women Referring to Afzalipour Hospital, Kerman, Iran ${ }^{\text {a }}$

\begin{tabular}{|c|c|c|c|}
\hline Characteristic $^{b}$ & Total & Pregnant Group, $N=76$ & Abortion Group, $\mathrm{N}=124$ \\
\hline \multicolumn{4}{|l|}{ Age (year) } \\
\hline$\leq 25$ & $62(31)$ & $25(32.9)$ & $37(29.8)$ \\
\hline $26-35$ & $99(49.5)$ & $40(52.6)$ & $59(47.8)$ \\
\hline$>35$ & $35(17.5)$ & $7(9.2)$ & $28(22.6)$ \\
\hline $1-10$ & $50(25)$ & $2(2.6)$ & $48(38.7)$ \\
\hline $11-20$ & $75(37.5)$ & $3(3.9)$ & $76(61.3)$ \\
\hline $21-30$ & $14(7)$ & $10(13.2)$ & 0 \\
\hline $31-40$ & $60(30)$ & 60 (78.9) & 0 \\
\hline$>40$ & $1(5)$ & $1(1.3)$ & 0 \\
\hline \multicolumn{4}{|l|}{ Locality } \\
\hline Kerman & $92(46)$ & $34(44.7)$ & $58(46.8)$ \\
\hline Township & $87(43.5)$ & $32(42.1)$ & $55(44.4)$ \\
\hline Others & $14(7)$ & $3(3.9)$ & $11(8.9)$ \\
\hline \multicolumn{4}{|l|}{ Mother education } \\
\hline Under diploma & $70(35)$ & $28(36.8)$ & $42(33.9)$ \\
\hline Diploma & $74(37)$ & $27(35.5)$ & $47(37.9)$ \\
\hline Upper diploma & $49(24.5)$ & $14(18.4)$ & $35(28.2)$ \\
\hline \multicolumn{4}{|l|}{ Patient's job } \\
\hline Housekeeper & $167(83.5)$ & $59(77.6)$ & $108(87.1)$ \\
\hline Employee & $26(13)$ & $10(13.2)$ & $16(12.9)$ \\
\hline Governmental & $46(23)$ & $16(21.1)$ & $30(24.2)$ \\
\hline Non-governmental (driver,...) & $147(73.5)$ & $53(69.7)$ & $94(75.8)$ \\
\hline \multicolumn{4}{|l|}{ Intercourse (week) } \\
\hline$\leq 3$ & $161(80.5)$ & $56(73.7)$ & $105(84.7)$ \\
\hline$>3$ & $32(16)$ & $13(17.1)$ & $19(15.3)$ \\
\hline \multicolumn{4}{|l|}{ Contraception method } \\
\hline Withdrawal & $134(67)$ & $52(68.4)$ & $82(66.1)$ \\
\hline Condom & $23(11.5)$ & $6(7.9)$ & $17(13.7)$ \\
\hline Other & $36(18)$ & $11(14.4)$ & $25(20.1)$ \\
\hline \multicolumn{4}{|l|}{ Type of delivery } \\
\hline NVD & $78(39)$ & $27(35.5)$ & $51(41.1)$ \\
\hline Caesarian & $45(22.5)$ & $9(11.8)$ & $36(29)$ \\
\hline First delivery & $70(35)$ & $33(43.4)$ & $37(29.8)$ \\
\hline \multicolumn{4}{|l|}{ Previous TOP } \\
\hline None & $111(55.5)$ & $44(57.9)$ & $67(54)$ \\
\hline One or more & $82(41)$ & $25(32.9)$ & $57(46)$ \\
\hline
\end{tabular}

History of genital infection 


\begin{tabular}{|c|c|c|c|}
\hline Yes & $78(39)$ & $27(35.5)$ & $51(41.1)$ \\
\hline No & $115(57.5)$ & $42(55.3)$ & $73(58.9)$ \\
\hline \multicolumn{4}{|c|}{ History of genital surgery } \\
\hline Yes & $22(11)$ & $10(13.2)$ & $12(9.7)$ \\
\hline No & $171(85.5)$ & $59(77.6)$ & $112(90.3)$ \\
\hline \multicolumn{4}{|c|}{ History of PROM } \\
\hline Yes & $38(19)$ & $13(17.1)$ & $25(20.2)$ \\
\hline No & $155(77.5)$ & $56(73.7)$ & $99(79.8)$ \\
\hline
\end{tabular}

Abbreviations: NVD, normal vaginal delivery; PROM, premature rupture of membranes; TOP, termination of pregnancy.

${ }^{a}$ Values are expressed as No. (\%).

${ }^{\mathrm{b}}$ Information for seven patients is not available. 
Table 4. Distribution of Demographic Factors in Pregnant Women with M. genitalium, C. trachomatis, and U. urealyticum Infection Admitted to Afzalipour Hospital, Kerman, $2017^{\mathrm{a}, \mathrm{b}}$

\begin{tabular}{|c|c|c|c|c|c|c|}
\hline Characteristic & C. trachomatis & PValue & M. genitalium & P Value & U. urealyticum & PValue \\
\hline Age (year) & & 0.932 & & 0.972 & & 0.691 \\
\hline$\leq 25$ & $3 / 25(12)$ & & $4 / 25(16)$ & & $3 / 25(12)$ & \\
\hline $26-35$ & $4 / 40(10)$ & & $7 / 40(17.5)$ & & $8 / 40(20)$ & \\
\hline$>35$ & $1 / 7(14.29)$ & & $1 / 7(14.29)$ & & $1 / 7(14.29)$ & \\
\hline $1-10$ & $0 / 2(0)$ & & $0 / 2(0)$ & & $0 / 2(0)$ & \\
\hline $11-20$ & $0 / 3(0)$ & & $0 / 3(0)$ & & $1 / 3(33.33)$ & \\
\hline $21-30$ & $1 / 10(10)$ & & $3 / 10(30)$ & & $0 / 10(0)$ & \\
\hline $31-40$ & $6 / 60(10)$ & & $10 / 60(16.67)$ & & $11 / 60(18.34)$ & \\
\hline$>40$ & $1 / 1(100)$ & & $0 / 1(0)$ & & $0 / 1(0)$ & \\
\hline Kerman & $6 / 34(17.65)$ & & $2 / 34(5.88)$ & & $5 / 34(14.70)$ & \\
\hline Township & $2 / 32(6.25)$ & & $9 / 32(28.12)$ & & $6 / 32(18.75)$ & \\
\hline Others & $0 / 3(0)$ & & $1 / 3(33.34)$ & & $1 / 3(33.33)$ & \\
\hline Mother's education & & 0.406 & & 0.866 & & 0.375 \\
\hline Under diploma & $3 / 28(10.72)$ & & $5 / 28(17.85)$ & & $5 / 28(17.85)$ & \\
\hline Diploma & $2 / 27(7.41)$ & & $4 / 27(14.81)$ & & 3/27(11.11) & \\
\hline Upper diploma & $3 / 14(21.43)$ & & $3 / 14(21.42)$ & 0.235 & $4 / 14(28.57)$ & \\
\hline Patient's job & & 0.327 & & & & 0.556 \\
\hline Housekeeper & $6 / 59(10.17)$ & & $9 / 59(15.25)$ & & $10 / 59) 16.94)$ & \\
\hline Employee & $2 / 10(20)$ & & $3 / 10(30)$ & & $2 / 10(20)$ & \\
\hline Governmental & $1 / 16(6.25)$ & & $2 / 16(12.5)$ & & $3 / 16(18.75)$ & \\
\hline Non - governmental (driver, ...) & $7 / 53(13.21)$ & & $10 / 53(18.86)$ & & $9 / 53(16.98)$ & \\
\hline Intercourse (week) & & 0.530 & & 0.402 & & 0.283 \\
\hline$\leq 3$ & $7 / 56(12.5)$ & & $9 / 56(16.07)$ & & $11 / 56(19.64)$ & \\
\hline$>3$ & $1 / 13(7.69)$ & & $3 / 13(23.07)$ & & $1 / 13(7.69)$ & \\
\hline Contrace ption method & & 0.361 & & 0.851 & & 0.851 \\
\hline Withdrawal & $7 / 52(13.46)$ & & $10 / 52(19.23)$ & & $10 / 52$ & \\
\hline Condom & $1 / 6(16.67)$ & & $1 / 6(16.67)$ & & $1 / 6(16.67)$ & \\
\hline Others & $0 / 11(0)$ & & 1/11(9.09) & & $1 / 11(9.09)$ & \\
\hline Type of delivery & & 0.050 & & 0.309 & & 0.543 \\
\hline NVD & $1 / 27(3.7)$ & & $3 / 27(11.11)$ & & $3 / 27(11.11)$ & \\
\hline Caesarian & $3 / 9(33.34)$ & & $3 / 9(33.33)$ & & $2 / 9(22.23)$ & \\
\hline First delivery & $4 / 33(12.13)$ & & $6 / 33(18.18)$ & & $7 / 33(21.21)$ & \\
\hline Previous TOP & & 0.107 & & 0.548 & & 0.221 \\
\hline None & $3 / 44(6.8)$ & & $8 / 44(18.18)$ & & $6 / 44(16.64)$ & \\
\hline One or more & $5 / 25(20)$ & & $4 / 25(16)$ & & $6 / 25(24)$ & \\
\hline History of genital infection & & 0.146 & & 0.127 & & 0.297 \\
\hline
\end{tabular}

Arch Clin Infect Dis. 2018; 13(6):e65334. 


\begin{tabular}{|c|c|c|c|c|c|c|}
\hline Yes & $5 / 27(18.51)$ & & $5 / 27(18.51)$ & & $6 / 27(33.33)$ & \\
\hline No & $3 / 42(7.14)$ & & $7 / 42(16.67)$ & & $6 / 42(14.29)$ & \\
\hline History of genital surgery & & 0.327 & & 0.544 & & 0.556 \\
\hline Yes & $2 / 10(20)$ & & $0 / 10(0)$ & & $2 / 10(20)$ & \\
\hline No & $6 / 59(10.16)$ & & $12 / 59(20.33)$ & & $10 / 59(16.95)$ & \\
\hline History of PROM & & 0.470 & & 0.402 & & 0.402 \\
\hline Yes & 2/13 (15.38) & & 3/13(23.07) & & 3/13(23.07) & \\
\hline No & $6 / 56(10.71)$ & & 9/56(16.07) & & $9 / 56(16.07)$ & \\
\hline
\end{tabular}

Abbreviations: NVD, natural vaginal delivery; PROM, premature rupture of membranes; TOP, termination of pregnancy.

${ }^{\mathrm{a}}$ Values are expressed as No. (\%).

$\mathrm{b}^{*}$ Statistically significant. 
Table 5. Distribution of Demographic Factors in Patients with Abortion with M. genitalium, C. trachomatis, and U. urealyticum Infection Admitted to Afzalipour Hospital, Kerman, $2017^{\mathrm{a}, \mathrm{b}}$

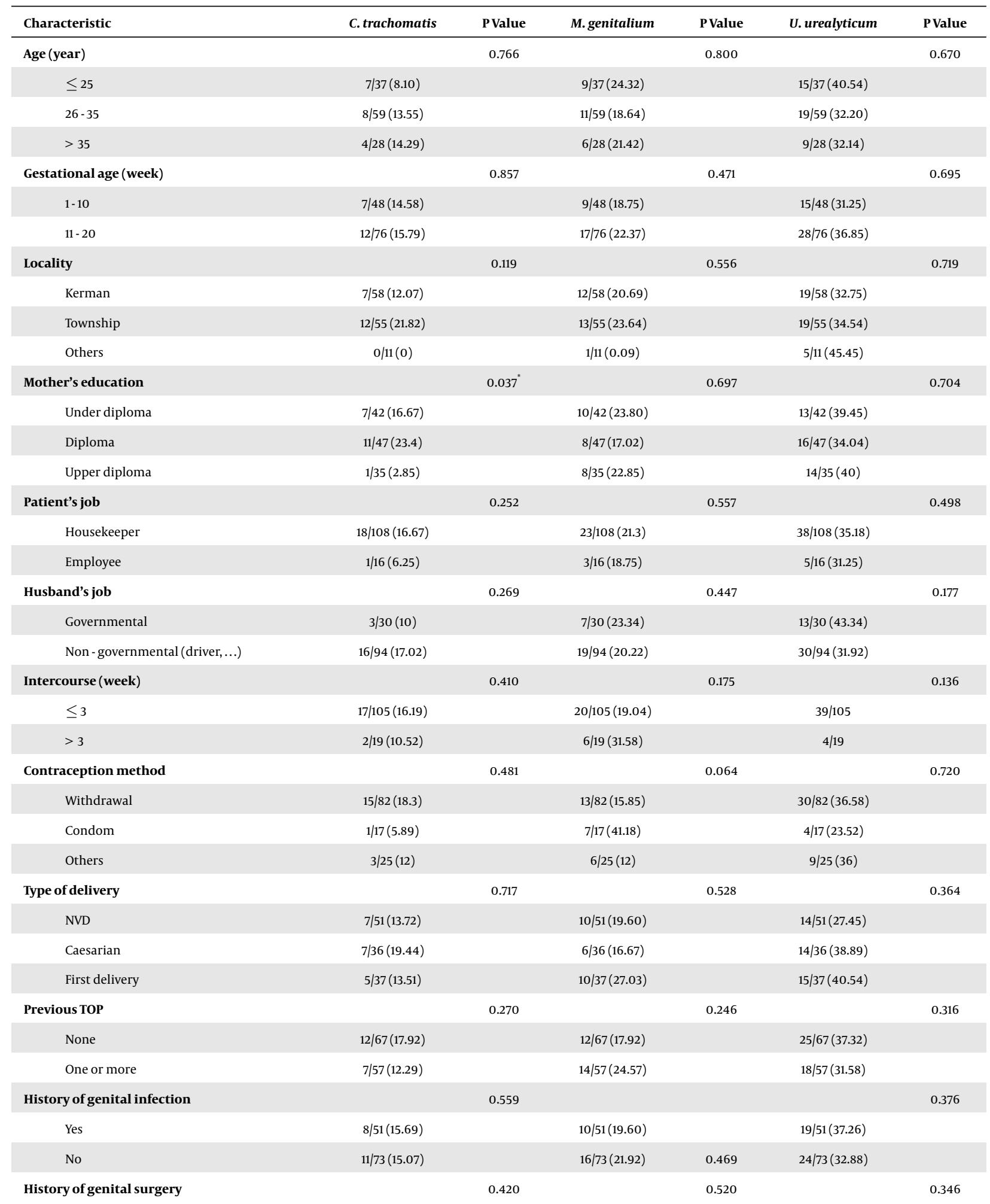

Arch Clin Infect Dis. 2018; 13(6):e65334. 


\begin{tabular}{|ccccc}
\hline Yes & $1 / 12(8.34)$ & $2 / 12(16.67)$ & $3 / 12(25)$ & $40 / 112(35.72 \%)$ \\
\hline No & $18 / 112(16.07)$ & $24 / 112(21.42)$ & 0.240 \\
\hline History of PROM & & 0.326 & 0.474 \\
\hline Yes & $5 / 25(20)$ & $7 / 25(28)$ & $3 / 25(32)$ & $35 / 99(35.35)$ \\
\hline
\end{tabular}

Abbreviations: NVD, natural vaginal delivery; PROM, premature rupture of membranes; TOP, termination of pregnancy.

${ }^{a}$ Values are expressed as No. (\%)

$\mathrm{b}^{*}$ Statistically significant. 